Utah State University

DigitalCommons@USU

$\mathrm{Bu}$

Bee Lab

$1-1-1903$

\title{
XX. - On Some New Genera and Species of Parasitic and Fossorial Hymenoptera from the Khasia Hills, Assam.
}

Peter Cameron

Follow this and additional works at: https://digitalcommons.usu.edu/bee_lab_bu

Part of the Entomology Commons

\section{Recommended Citation}

Cameron, Peter, "XX. - On Some New Genera and Species of Parasitic and Fossorial Hymenoptera from the Khasia Hills, Assam." (1903). Bu. Paper 187.

https://digitalcommons.usu.edu/bee_lab_bu/187

This Article is brought to you for free and open access by the Bee Lab at DigitalCommons@USU. It has been accepted for inclusion in Bu by an authorized administrator of DigitalCommons@USU. For more information, please contact digitalcommons@usu.edu.

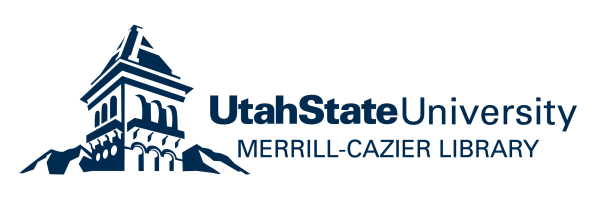


On new Hymenoptera from the Khasia Hills.

tant qu'on est malgré tout forcé de souftirir. Jugez d'après cela de ce que sont les nuits passées en plein air sur les bords du Pasvik, j'étais bien heureux do rencontrer en passant do pauvres cabanes éclairées par la cheminée soule; j'entrais à genoux dans ces réduits enfumés où j'avais au moins la satisfaction de reposer tranquillement a l'abri des insupportables dipteres. Une exploration scientifique est assez méritoire dans les pareilles conditions."

[To ba continued.]

XX.-On some new Genera and Species of Parasitic and Fossorial Hymenoptera from the Khasia Hills, Assam. By P. Casieron.

Ichneumonidæ.

JOPPINI.

IмеRiA, gen. nov.

Head large, cubital, largely developed behind the eyes"; the occiput roundly convex, its sides not distinctly margined. Eyes parallel; the malar space large. Clypeus not separated from the face, indistinctly foveate at the base. Mandibles large; their apex with two large, equal, widely separated, long, sharply pointed teeth. Scutellum longer than broad; its sides with large, narrow, leaf-like keels. Median segment areolated at the base; the sides of the apex sharply keeled, the middle of the keel with a blunt tooth; the spiracles elongate, curved, broadest at the base. Prosternum large, leaf-like below, with a distinct margin. Legs: the fore tarsi twisted at the base. Abdomen not much longer than the head and thorax united, with eight segments; the rentral fold on the second and third segments; the ovipositor largely projects. Areolet oblique, almost triangular. Antennæ dilated and compressed towards the apex.

Belongs to the Joppini and resembles somewhat the Neotropical genus Edicephalus. It comes near Xenojoppo, Cam., olim Margrettia, Cam., from which it may be known by the hinder coxæ not being toothed, by the keels on the scutellum not being raised and leaf-like, by the face and clypeus forming one piece, by the petiole not being perceptibly thickened towards the apex, by its spiracles being

Ann. \& Mag. N. Hist. Ser. 7. Vol. xi. 13 
much smaller, rounder, and not nearly so elongated, and by the dorsal segments not being longitudinally striated. Characteristic is the fact that the longitudinal keels on the metanotum are obsolete, and, on the other hand, there are transverse ones, as in the Cryptina. The mandibles are peculiar; they are broad at the base, project largely downwards below the head, and appear as if they were attached by the upper part only and not by the whole width of the base.

The differences between Imeria, Xenojoppa, and Habro. joppa may be slown thus :-

A. Abdomen with seven dorsal segments, the mesonotum coarsely reticulated, mandibles and fore coxæ normal.

Postpetiole widely dilated at the apex as in the Platyuri, clearly separated, the hinder coxie toothed ..........................

Postpetiole not widely dilated, not clearly separated from the petiole, the hinder corr not toothed .

B. Abdomen with eight dorsal segments. Mandibles very broad, thick, and develuped straight downwards at the base; the fore coxæ large, globular, largely developed behind the base of the trochanters; the mesonotum not reticulated .............

\section{XENOJOPPA.}

IIABROJOPPa.

IMFrI.

\section{Imeria albomaculata, sp. $\mathbf{n}$.}

Black, shining; a line, broad and oblique on the top, gradually narrowed towards the apex, on the inner, a somewhat oblong one on the outer orbits, not reaching to the bottom of the eyes, a mark, broadly, triangularly dilated on the outer side beneath, on the outer lower orbits, the clypeus except a small black mark in the middle above, the mandibles except the teeth, the palpi, the base of the pronotum, the yellow continued more narrowly to the end of the pleura, a short line on the sides in front of the tegulæ, tubercles, an irregular somewhat triangular mark on the lower side of the mesopleuræ, at the apex, the scutellum, postscutellum, a large triangular mark on the side of the median segment before the spiracles, the apex of the median segment, following the outlines of the arex, thus being somewhat triangular above, and laterally on the lower side continued into the spiracular area immediately over the coxæ, yellow. Wings hyaline, the stigma testaceous, the nervures darker. Thie four anterior legs rufo-fulvous, with their coxæ and trochanters white; the hinder coxæ black, their apical three fourtls white above; the hinder trochanters and femora rufo-fulvous; the basal joint of the

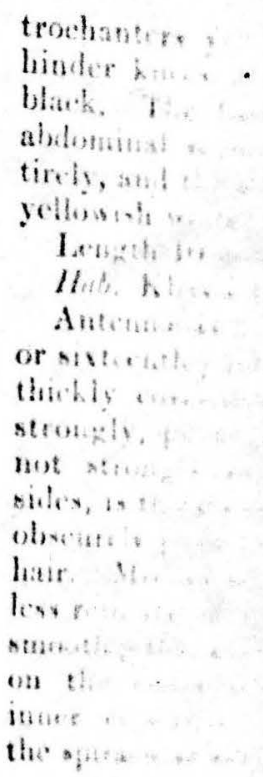

B: $: 5:$

white to.

sidex it

a $!$ :

side it

sit: + : :

in: $:+1$

the

i.t.i.

1.

1.: i. a. .

I1. I :

cheng $+x$

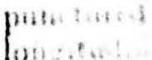

mush in

Hitin at

Stwitis:

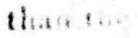

it is ,

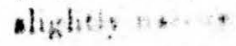

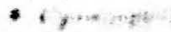




$$
\text { Hymenoptera from the Khasia Hills. }
$$

trochanters yellow above, blackish on the inner side; the hinder knees, the apex of the tibix, and the trochanters black. The base of the petiole, of the second and third abdominal segments broadly, the apical two segments entirely, and the apices of the middle segments very narrowly, yellowish white. $q$.

Length $10 \mathrm{~mm}$.

Hab. Khasia Hills. Coll. Rothney.

Antenne as long as the body; the ninth to the fifteenth or sixteenth joints white; the scape strongly punctured and thickly covered with fuscous hair. Face closely, but not strongly, punctured. Mesonotum closely, uniformly, but not strongly rugosely punctured, and, especially at the sides, is thickly covered with short fuscous hair. Scutellum obscurely punctured and sparsely covered with long fuscous hair. Median segment closely aud strongly rugose, more or less reticulated; its extreme base in the middie depressed, smooth; the supra-external arex large, wider than long; on the outer side closely longitudinally striated, on the inner closely and coarsely aciculated, almost punctured; the spiracular area is aciculated.

$$
\text { Cyanojoppa * corulea, sp. n. }
$$

Blue, the head, thorax, and legs thickly covered with white pubescence; the inner orbits, a small mark on the sides of the clypeus, a longish line on the outer orbits, a line on the apical two thirds of the pronotum, the outer side of the tegulæ, the tubercles, and a mark on the lower side of the mesopleuræ at the base, yellowish white; the wings fuscous violaceous, the nervures and stigma black; the apex of the four front femora and the four anterior tibia in front yellowish white. $q$.

Length $15 \mathrm{~mm}$.

Hab. Khasia Hills. Coll. Rothney.

Head and thorax thickly covered with white pubescence, closely and distinctly punctured; the scutellum more sparsely punctured than the mesonotum, the postscutellum closely longitudinally striated. The lower half of the propleuræ is much more strongly punctured than the upper; the punctuation almost forms reticulations. Metathorax closely and strongly punctured; the base is more sparsely punctured than the rest; the areola is widely separated from the base; it is slightly longer than broad, open at the base, and slightly narrower there than it is at the apex; its sides are

- Cyañjoppa, Cam. Zeits. f. Flymen. u. Dipt. 1902, p. 398. 
roundly curved ontwardly, its apex is roundly, but not much curved inwardly. The postpetiole is elosely longitudinally striated; there may be two small white marks on its apex. The second and following segments are elosely and somewhat strongly punctured; the base of the second is longitudinally striated; the gastrocœli are obscurely striated at the base.

\section{Cyanojoppa albonotata, sp. n.}

Blue, the head and thorax covered with white pubescence the inner orbits, the outer more narrowly in the middle, the sides of the clypeus, an irregular mark outside the middle, the maxillary palpi except at the base, a line on the pronotum, the tubercles, the apex and the apical half of the sides, and two small marks on the apex of the basal three segments of the abdomen, yellowish white; the wings fuscous violaceous, the nervures and stigma black. $\delta$.

Length $15 \mathrm{~mm}$.

$H a b$. Khasia Hills. Coll. Rothney.

Head and thorax closely and somewhat strongly puncture? ; the apex of the propleuræ more or less striated ; the apex of the postscutellum impunctate in the middle. The areola has the hasal half somewhat more distinctly narrowed than the apical; its sides are foveate, the central part irregularly shagreened; the posterior median area distinetly projects triangularly into it and is closely rugosely punctured; the spiracular area, except at the base, is coarsely irregularly reticulated. Postpetiole finely and closely striated at the base, the apex almost smooth. The second and following segments have a distinct purple tint; the second, third, and fourth are closely and rather strongly punctured, the second in the middle at the base is strongly longitudinally striated; the gastrocceli have a few stout keels at the base. Legs coloured like the body; the four front coxæ, femora, and tibiæ are more or less yellowish beneath.

\section{Cyanojoppa striata, sp. $\mathrm{n}$.}

Black; the abdomen blue, marked with purple; the head and thorax thickly covered with white pubescence; the inner eye-orbits, the base of the clypeus at the sides, a mark on the base of the mandibles, a narrow line on the edge of the pronotum, the scutellar keels, the tubereles, and a small mark on the base of the mesopleure, white; the basal half of the hinder femora red; the wings almost hyaline, the nervures and stigma black. $\delta$.

Length $15 \mathrm{~mm}$.

Hab. Khasia Hills, Coll. Rothney.

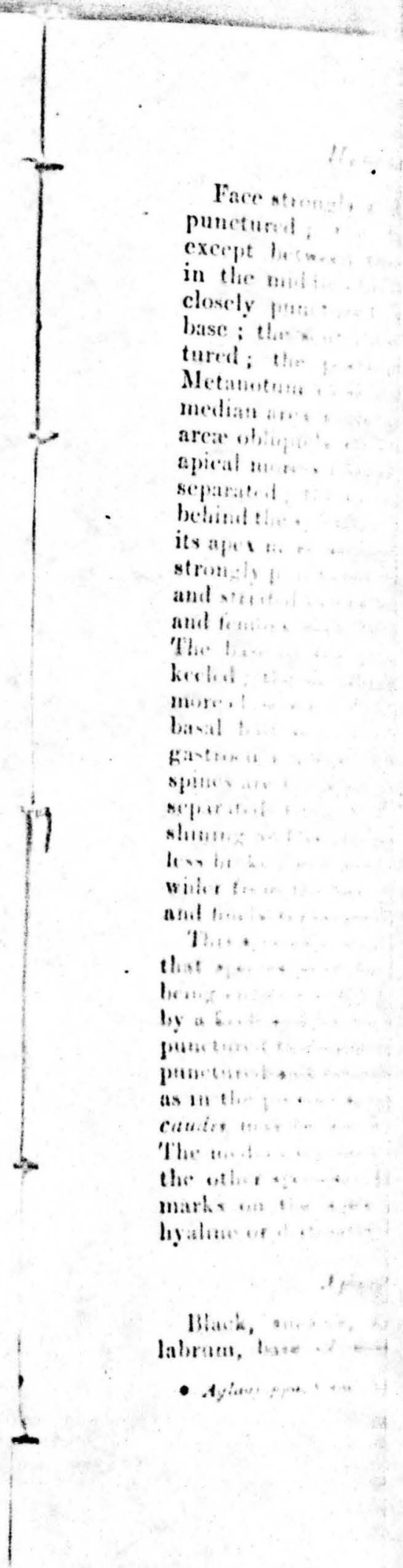


IIymenoptera from the Khasia IIills.

Face strongly and closely, the clypeus still more strongly, punctured; the front and vertex strongly punctured, except between the eyes and the hinder ocelli; the front in the middle obscurely transversely striated. Mesonotum closely punctured, the parapsidal furrows indicated at the base; the scutellum as closely but not so strongly punctured; the postscutellum closely punctured at the base. Metanotum closely and distinctly punctured; the posterior median area more or less transversely striated; the lateral areæ obliquely striated, the basal one finely and closely, the apical more strongly and with the striæ distinct and clearly separated; the spiracular area is closely and weakly striated behind the spiracles, its middle closely and strongly obliquely, its apex more strongly and irregularly. Pleurae closely and strongly punctured, the propleure more strongly than the rest and striated in the middle at the apex. The four front tibiæ and femora may be more or less obscure yellow in front. The base of the petiole is smooth above and has its sides keeled; the middle is stoutly and irregularly and the apex more closely and finely striated. The second segment has the basal half stoutly and closely longitudinally striated; the gastrocœli are stoutly striated in the centre. The tarsal spines are blackish. The areola is small, broader than long, separated from the basal slope by a narrow keel; it is shining and is irregularly striated, the strix being more or less broken and irregular; it becomes gradually and slightly wider from the base to the apex; the basal slope is closely and finely transversely striated.

This species comes nearest to C. rufofemorata, Cam.; but that species may be known from it by the hinder femora bcing entirely red, by the areola being not separated behind by a keel, and by its being closely reticulated or irregularly punctured throughout, and by the lateral areæ being closely punctured and reticulated, not distinctly striated throughout as in the present species. $C$. nigroccerulea and $C$. corruleocaudis may be known from it by the much larger areola. The median segment is more strongly striated than it is in the other species. In some examples there are two white marks on the apex of the scutellum. The wings may be hyaline or distinctly fuscous throughout..

Aglaojoppa ${ }^{*}$ flavolineata, sp. $\mathrm{n}$.

Black, smooth, and shining; the face, orbits, clypens, labrum, base of mandiples, palpi, two long lines on the

- Aglaojoppa, Can. Ann. \& Mag. Nat. Hist. ser. 7, vol. vii. p. 381. 
mesonotum, the scutellum, a mark on the base of the scutellar keels, the postscutellum, a small mark behind the spiracles, the outer apical area extending at the apex on to the spiracular, a broad band on the pronotum, a smaller line on the lower side of the propleurie, the lower half of the mesopleuræ except at the base and apex, the mesosternum, the tubercles, and a mark under the hinder wings, lemonyellow. The four anterior legs lemon-yellow, except the femora above and an interrupted line on the tibiæ; the hinder coxæ, femora, and apical third of the tibiæ black. The apex of the petiole, a large mark on the sides of the second, third, fourth, and fifth segments at the apex, lemonyellow; the marks on the second larger, on the fifth much smaller than on the others. Wings violaceous fuscous, paler at the base; the stigma and nervures black. $\delta$.

Length $15 \mathrm{~mm}$.

$H a b$. Khasia Hills. Coll, Rothney.

The scape and the basal third of the flagellum yellowish fulvous beneath. Face and clypeus sparsely punctured, the sides and apex of the clypeus smooth. Mesonotum covered with large, rather widely separated punctures and with rather long fuscous hair ; the scutellum with longer and somewhat paler hair. Areola twice broader than long; its basal keel semicircular and not so clearly defined as the others; the posterior median area coarsely punctured, except at the extreme base; all the punctures are deep and distinctly defined. Pro- and mesopleurre with shallow punctures; the apex of the propleuræ coarsely, deeply, and irregularly punctured; of the mesopleuræe crenulated, the lower part with a small upper and a much larger lower fovea. Petiole smooth, neither punctured nor striated. Gastrocœli large, deep, their base with five diverging striæ; the space between them closely striated; the second to fifth segments are closely punctured.

\section{Aglaojoppa femorata, sp. n.}

Comes near to $A$. flavomaculata, but the yellow markings are much less extensive (there are only four on the abdomen), the mark on the mesopleuræ is much smaller, the two marks on the mesonotum are shorter, and the areola is more clearly defined.

Black, shining; the scape of antennæ below, the face, clypeus, labrum, base of mandibles, the palpi, the inner orbits, the lower two-thirds of the outer more broadly, the edge of the pronotum broadly except at the apex, two short marks us $\ell_{1}$. scutellum, notum, a bar:e, ti.2. on the hise pleurat withos on thats violareens yollon: : behund te. behind, th joint of t blach; a : the pute stegrtene

$1 \ldots$

llab is

'The 1 ., oblinge and in : posterwe striated, the sus atriate: clowels derpe conchut? whit ot the propilene

\section{III i $^{2}$ \\ m.x...}

belone,

in 1 l. . . .

seldtwhes

puatents.

behmd, at

narrouls aseo

the entiente.

the hased

sparates, a

the sidis of

a main wis ?

thexc warks lactotat 


$$
\text { IIymenoptera from the Khasia Hills. }
$$

marks on the middle of the mesonotum, scutellum, postscutcllum, the greater part of the lateral arex of the metanotum, the lower part of the propleurx, the tubercles, a large mark, slightly longer than broad, on the mesopleura on the lower side near the base, a small mark on the metapleuræe under the wings, and a larger irregularly oval mark on their centre, lemon-yellow. Wings uniformly fuscous violaceous; the stigma and nervures black. Legs lemonyellow; the four anterior femora broadly, the fore tibix behind throughout, the middle and hinder pair at the base behind, the basal half of the hinder femora, and the basal joint of the hinder tarsi black at the base. Abdomen black; a mark obliquely narrowed behind on the apex of the petiole, and two larger marks on the apex of the second segment, lemon-yellow. $\delta$.

Length $15 \mathrm{~mm}$.

Hab. Khasia Hills. Coll. Rothney.

The base of the median segment is smooth, its middle obliquely depressed; the areola is slightly longer than broad, and is gradually and slightly widened towards the apex; the posterior median area is closely, rugosely, transversely. striated; the outer apical arex stoutly obliquely striated; the spiracular finely rugose at the base, its apex stoutly striated. The second and third abdominal segments are closely punctured and striated. in the middle; the gastrocœli deep, obscurely striated at the base. Face and clypeus covered, but not closely, with large punctures and sparsely with short white hair; the clypeal fover large. Apex of propleuræ depressed, irregularly striated.

\section{Aglaojoppa caruleodorsata, sp. n.}

Black; the face, inner orbits, clypeus, labrum, base of mandibles broadly, the inner orbits narrowly above, broadly below, the edge of the pronotum broadly, two short marks in the centre of the mesonotum, a mark on the sides of the scutellum, broad behind, narrowed to a point at the apex, postscutellum, a mark on the lower side of the propleura behind, a large mark reaching to near the apex and prolonged narrowly upwards at the base, the mesosternum in the middle, the tubercles, a small and a large mark immediately under the hind wings, a curved one inmediately behind the spiracles, a large mark in front of them over the coxæ, the sides of the petiole broadly, its apex narrowly, and a mark on the abdominal segments 2 to 5 on the sides, these marks becoming successively smaller, yellow. The 
second and following segments of the abdomen blue; the second segment in the middle strongly longitudinally striated. Wings fuscous, the stigma black. $\delta$.

Length $16 \mathrm{~mm}$.

Hab. Khasia Hills. Coll. Rothney.

Antenna stont, the scape white beneath. Face and clypeus punctured, sparsely covered with short hair; the labrum projecting, rounded at the apex, and fringed with long pale hair. Mesonotum strongly punctured, the punctures becoming smaller towards the apex; the scutellum more strongly punctured than it in the middle. Postscutellum impunctate. Base of median segment smooth, with only a few scattered punctures; the areola is wider than long, and is separated by its own length from the base of the segment; the posterior intermediate area is strongly transversely striated; the posterior median area is wide and is closely transversely striated; the other areæ are closely rugosely punctured. Propleuræ obscurely striated behind, the mesopleuræ punctured, but not strongly; the metapleuræ more closely punctured and with a distinct keel on the lower side. Fore legs with the femora and tibire lined with black above, the middle femora lined with black to near the apex and all round at the base; the hinder femora black, except at apex; the metatarsus black, except at the apex; the base of the second joint narrowly black; the hind tibiæ black, broadly white at the base. The middle of the petiole is longitudinally striated. Areolet narrowed at the top, the nervures meeting there. .

This species is not quite a typical Aglaojoppa; the areolet is more narrowed at the top; the colour is paler, it being almost white, and the blue abdomen also separates it from the other species.

\section{Acanthojoppa * indica, sp. n.}

Luteous, marked with yellow; a black mark on the base of the mesonotum, a line along the base from the middle of the pronotum to the end of the tegula and the depression at the base of the scutellum yellow; the wings beyond the stigma fuscous, with a slight violaceous tint; the stigma dark testaceous. $\delta$.

Length $13 \mathrm{~mm}$.

Hab. Khasia Hills. Coll. Rothney.

Basal half of the antenna rufo-fulvous, the scape with a yellowish tinge on the lower side. The face and elypeus

*Acanthojoppa, Cam., 'The Entomologist,' 1899, p. 109.

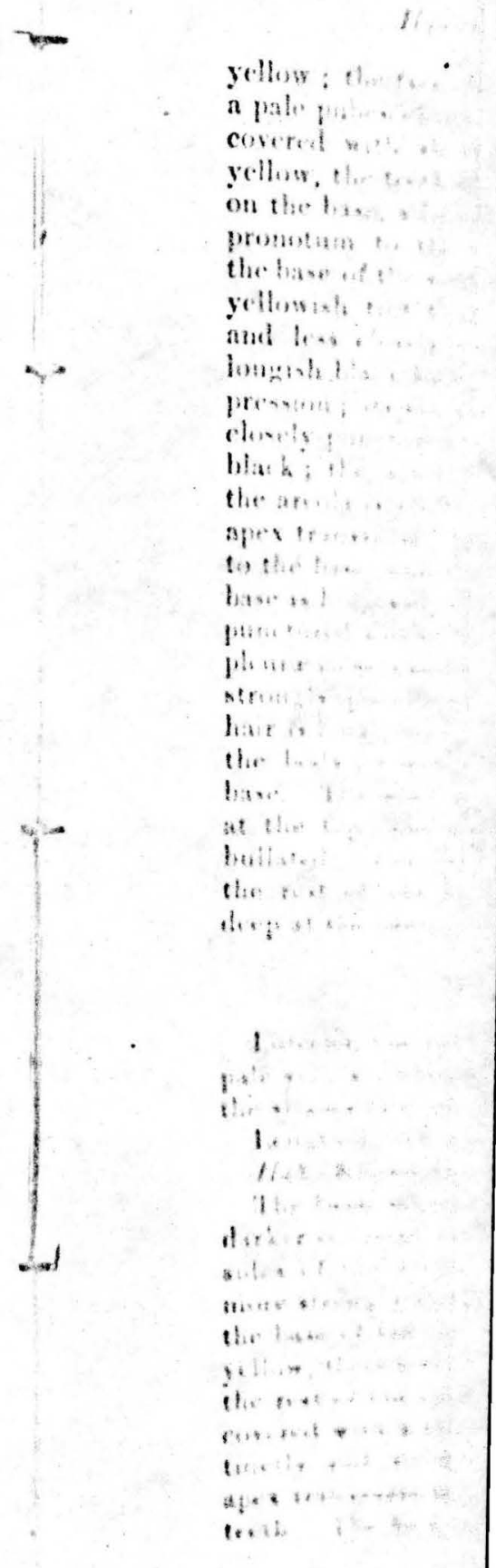


yellow; the face closely punctured, the clypeus covered with a pale pubescence; the vertex closely punctured and thickly covered with short blackish pubescence. Mandibles pale yellow, the teeth black. Mesonotum dark rufous, a mark on the base, a line along the base from the middle of the pronotum to the end of the tegula, and the depression at the base of the scutellum, black. Scutellum paler, of a more yellowish tint than the mesonotum; it is more distinctly and less closely punctured, and is covered all over with longish black hair; its apex, on the top, has a shallow depression; its sides are not keeled. Metanotum strongly and closely punctured; its sides, base, and apex bordered with black; the apical half of the posterior median area black: the areola is about as broad as long, its base is rounded, its apex transverse; inside it is a stout central keel, not reaching to the base, and there is an oblique one on either side, the base is hollowed. The upper half of the propleuræ is closely punctured and striated obliquely on the lower side. Mesopleure closely and distinctly punctured; the metapleuræ more strongly punctured, behind the keel stoutly striated; the hair is long, close, and fuscous in colour. Legs coloured like the body; the four anterior paler, more yellowish at the base. The wing-areolet is triangular, the nerrures touching at the top; the second transverse cubital nervure is widely bullated. The petiole is smoother and more shining than the rest of the body; the gastroccli narrow, smooth, and deep at the base.

\section{Acanthojoppa lutea, sp. n.}

Luteous, the apical half of the antennæ black, the basal pale yellow; the wings fuscous hyaline, the apex violaceous, the stigma luteous, the nervures black. $q$.

Length 17-18 mm.

Hab. Khasia Hills. Coll. Rothney.

The basal seventeen joints of the antennæ are yellowish, darker coloured at the base. The inner eyc-orbits and the sides of the clypeus broadly pale yellow. Hace punctured, more strongly and closely in the middle than on the sides; the base of the clypeus sparsely punctured. Mandibies pale yellow, their teeth black. Mesonotum darker coloured than the rest of the thorax, coarsely and closely shagreened and covered with a short, close, dark pile. Scutellum more distiuctly and strongly punctured than the mesonotum; its apex transverse in the middle, its sides projecting into blunt teeth. The base of the median segment irregularly rugose, 
the lateral arex smooth at the base, the apex is stoutly transversely striated; the posterior median black, with the strix clo-er and narrower; the areola is large, longer than broad, its apical half obliquely narrowed; the teeth are large and rounded at the apex. On the thorax the following parts are black: the buse and sides of the median segment, the posterior median area, an oblique line below the middle of the propleuræ, the sides of the mesosternum at the base, and the pleura before the mesocoxæ. The wings have a distinct yellow tinge to the base of the stigma, the apex with a distinet fuscous-violaceous tint; the stigma luteous. Abdomen shining, the second and third segments closely punctured; the gastrocœli shallow, their outer side with a few obscure striæ.

The violaceous tint is much more distinct on the apex of the fore wings than in the other species, while the areola differs in being sharply narrowed on the apical half.

\section{Xanthojoppa ${ }^{*}$ nigrolineata, sp. $\mathrm{n}$.}

Length $20 \mathrm{~mm}$. $\delta$.

Hab. Khasia Hills. Coll. Rothnev.

Yellow; the front and vertex broadly in the middle, the former more broadly than the latter and the occiput still more broadly, the sides and apex of the mesonotum broadly, the latter more narrowly than the sides, a broad band in its centre at the base and extending to shortly beyond the centre, the band dilated and rounded at the apex, the space at the base of the scutellum, including the fover, the depression at its sides, the base of the median segment, its apex with the teeth, the black band projecting in the middle, the middle of the propleuræ, the mesopleure round the top and at the apex, the base of the second abdominal segment, its apex narrowly and it has a faint central line, which is narrowed and faint at the base, the base of the petiole and the third and following segments broadly down the centre, black. Wings fuscous violaceous, the nervures and stigma black. Legs coloured like the body; the hisder tarsi, except at the extreme base and apex, black. The basal eight or nine joints of the antennæ are rufous, the others black or brownish; the scape yellow, almost smooth and sparsely covered with black hair. Face and clypeus smooth, shining, impunctate, and sparsely covered with white hair; the labrum fringed with golden hair. Mesonotum shining, closely, but not strongly, punctured and thickly covered with short fuscous

- Xanthojoppa, Cam. Ann. \& Mag. Nat. Hist. ser. 7, vol. vii. p. 378.

\section{Il}

hair, S S.t.

hair. I?

deeply : : : 1

on the n.......

kecl. T

the :aroth : :

posterior th

longaturiti:

the wh : :

Meroglt on,

coaroly at

next in tl

Metaytum

bawe ! !

dilatid,

tudimalto.

ou' $\mathrm{r}$

by at

het.tid.

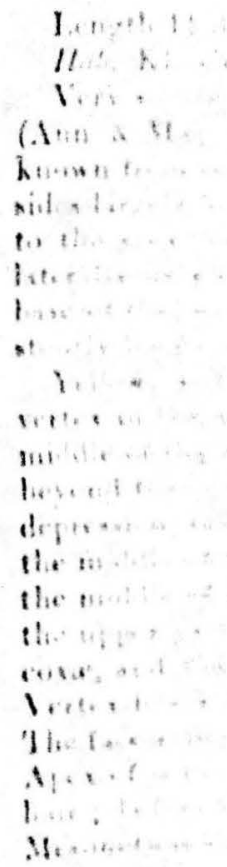


hair. Scutellum punctured and thickly covered with fuscous

hair. Postscutellum very smonth and shining, glabrous, deeply and widely fovente laterally. The central depression on the median segment is bordered behind by a short stout keel. The rest of the segment is conrsely rugosely punctured; the areola is open behind and is longer than broad; the posterior median and lateral apical area coarsely reticulated, longitudinally is the middle, more coarsely transversely at the sides; the teeth stout, black. Propleuræe above punctured. Mesopleuræ shining, the black upper part shagreened, more coarsely at the apex below, the upper part raised, the lower, next to the sternum, al =o projecting, but not so strongly. Metapleuræ strongly obliquely striated, less strongly at the base. Petiole smooth and shining, the apex triangularly dilated, the base of the second segment strongly longitudinally striated; the gastrocœli elongate, smooth on the outer side, the apex testaccous and separited from the rest by a stout transverse keel; the base of the petiole is stoutly keeled down the middle and less stoutly at the sides.

\section{Xanthojoppa crassispina, sp. $\mathrm{n}$.}

Length $11-12 \mathrm{~mm}$. $q$.

Hab. Khasia Hills. Coll. Rothney.

Very similar in form and coloration to $X$. trilineata, Cam. (Ann. \& Mag. Nat. Hist. ser. 7, vol. vii. p. 378), but nay be known from it by the form of the scutellum, which has the sides largely bordered by leaf-like expansions from the base to the apex, by the depression at the base being bordered laterally by a stout keel, by there being three arere on the base of the median segment, and by the gastrocceli being stoutly longitudinally striolated.

Yellow, suffused with fulvous; the ocellar region, the vertex in the middle, the front broadly, a broad line on the middle of the mesonotum extending from the base to shortly beyond the middle, the sides near the tegulæ, the scutellar depression, the depression at the base of the median segment, the middle of the areola, the posterior median area entirely, the middle of the propleuræ, the base of the mesopleuræ and the upper part below the tubercles, a mark over the middle coxæ, and the base and lower side of the metapleuræ, black. Vertex finely punctured, the front very smooth and shining. The face and base of the clypeus with large shallow punctures. Apex of mandibles black, the base covered with soft white hair ; before the apex on the lower side with golden hair. Mesonotum closely punctured, dull yellow, suffiused at the 